\title{
Effect of the strontium aluminate and hemihydrate contents on the properties of a calcium sulphoaluminate based cement
}

\author{
G. Velazco $\bowtie$, J.M. Almanza, D.A. Cortés, J.C. Escobedo, J.I. Escalante-Garcia
}

Cinvestav Saltillo (Coahuila, México)

$\triangle$ gerardo.velazco@cinvestav.edu.mx

\author{
Received 7 June 2013 \\ Accepted 29 July 2013 \\ Available on line 20 August 2014
}

\begin{abstract}
The effect of strontium aluminate $\left(\mathrm{SrAl}_{2} \mathrm{O}_{4}\right)$ on the hydration process of a calcium sulphoaluminate $\left(\mathrm{C}_{4} \mathrm{~A}_{3} \hat{\mathrm{S}}\right)$ cement was investigated. Cement pastes were prepared by mixing $\mathrm{C}_{4} \mathrm{~A}_{3} \hat{\mathrm{S}}$, hemihydrate $\left(\mathrm{CaSO}_{4} \cdot 1 / 2 \mathrm{H}_{2} \mathrm{O}\right.$, $\mathrm{CSSH}_{0.5}$ ) and 0,10 or $20 \mathrm{wt} \%$ of $\mathrm{SrAl}_{2} \mathrm{O}_{4}(\mathrm{SrA})$. The amount of $\mathrm{CS}_{0.5}$ was 15,20 or $25 \mathrm{wt} \%$ based on the $\mathrm{C}_{4} \mathrm{~A}_{3} \hat{\mathrm{S}}$ quantity. The cement pastes were hydrated using water to cement ratios (w/c) of 0.4 and 0.5 . Samples were cured from 1 to $28 \mathrm{~d}$. The compressive strength and setting time were evaluated and the hydration products were characterized. It was found that the setting time was delayed up to $42 \mathrm{~min}$ for the samples containing $\mathrm{SrAl}_{2} \mathrm{O}_{4}$ compared to samples without addition. The samples with $25 \mathrm{wt} \%$ hemihydrate containing $20 \mathrm{wt} \% \mathrm{SrAl}_{2} \mathrm{O}_{4}$ developed the highest compressive strength $(60 \mathrm{MPa})$ after $28 \mathrm{~d}$ of curing. The main product after hydration was ettringite $\left(\mathrm{C}_{6} \mathrm{AS}_{3} \mathrm{H}_{32}\right)$. The morphology of this phase consisted of thin needle-shaped crystals.
\end{abstract}

KEYWORDS: Strontium aluminate; Ettringite; Sulphoaluminate

Citation / Citar como: Velazco, G.; Almanza, J.M.; Cortés, D.A.; Escobedo, J.C.; Escalante-Garcia, J.I. (2014). Effect of the strontium aluminate and hemihydrate contents on the properties of a calcium sulphoaluminate based cement. Mater. Construcc. 64 [315], e024. http://dx.doi.org/10.3989/mc.2014.04413.

RESUMEN: Efecto del contenido de aluminato de estroncio y hemihidrato sobre las propiedades de un cemento de sulfoaluminato de calcio. Se investigó el efecto de la adición de aluminato de estroncio $\left(\mathrm{SrAl}_{2} \mathrm{O}_{4}\right)$ sobre las propiedades de un cemento de sulfoaluminato de calcio $\left(\mathrm{C}_{4} \mathrm{~A}_{3} \hat{\mathrm{S}}\right)$. Se prepararon muestras mezclando $\mathrm{C}_{4} \mathrm{~A}_{3} \hat{\mathrm{S}}$, hemihidrato $\left(\mathrm{CaSO}_{4} \cdot 1 / 2 \mathrm{H}_{2} \mathrm{O}, \mathrm{CS} \mathrm{S}_{0.5}\right)$ y 0,10 o $20 \%$ e.p de $\mathrm{SrAl}_{2} \mathrm{O}_{4}(\mathrm{SrA})$. La cantidad de $\mathrm{CS}_{0.5}$ fue de 15,20 o $25 \%$ e.p. basado en la cantidad de $\mathrm{C}_{4} \mathrm{~A}_{3} \hat{\mathrm{S}}$. Las relaciones agua/cemento utilizadas fueron 0.4 y 0.5 . Las muestras fueron curadas hasta 28 d. Se evaluó el tiempo de fraguado y la resistencia a la compresión. Los productos de hidratación se caracterizaron mediante DRX y MEB. El tiempo de fraguado se retardó hasta 42 minutos con la adición del $\mathrm{SrAl}_{2} \mathrm{O}_{4}$ comparado con las muestras sin adiciones. Las muestras con $25 \%$ e.p. de yeso y $20 \%$ e.p. de $\mathrm{SrAl}_{2} \mathrm{O}_{4}$ desarrollaron la mayor resistencia a la compresión alcanzando $60 \mathrm{MPa}$ a $28 \mathrm{~d}$ de curado. Los análisis por MEB y DRX muestran como principal producto de hidratación a la etringita $\left(\mathrm{C}_{6} \mathrm{AS}_{3} \mathrm{H}_{32}\right)$, cuya morfología se observa como cristales aciculares.

PALABRAS CLAVE: Aluminato de estroncio; Etringita; Sulfoaluminato

Copyright: (C) 2014 CSIC. This is an open-access article distributed under the terms of the Creative Commons Attribution-Non Commercial (by-nc) Spain 3.0 License.

\section{INTRODUCTION}

The calcium sulphoaluminate $\left(\mathrm{C}_{4} \mathrm{~A}_{3} \hat{\mathrm{S}}\right)$ is the key component of calcium sulphoaluminate (CSA) based cements. These binders consist mainly of the phase ye'elemite, also called Klein's salt or tetracalcium trialuminate sulphate $\left(\mathrm{C}_{4} \mathrm{~A}_{3} \hat{\mathrm{S}}\right)$ (1). Recently, there has been a renewed interest in CSA cements because of their potential environmental benefits and performance advantages in special applications, and their rise in popularity has been accompanied with some state of the art reviews (2-4). The term CSA cements is usually reserved for those clinkers containing more than $50 \mathrm{wt} \%$ of Klein's salt and they may also have minor amounts of phases such as $\mathrm{C}_{2} \mathrm{~S}, \mathrm{CA}, \mathrm{C}_{4} \mathrm{AF}, \mathrm{CS}, \mathrm{CS}_{2}$ (5). 
Cements with large amounts of Ye'elimite may have special applications due to their high strength development at early-ages (6). It can be synthesized by calcining stoichiometric proportions of calcium carbonate $\left(\mathrm{CaCO}_{3}\right)$, aluminium hydroxide $\left(\mathrm{Al}(\mathrm{OH})_{3}\right)$ and gypsum $\left(\mathrm{CaSO}_{4} \cdot 2 \mathrm{H}_{2} \mathrm{O}\right)$ at temperatures ranging from 1250 to $1300{ }^{\circ} \mathrm{C}$ for $3 \mathrm{~h}$ (7). De la Torre et al. (8) studied the thermal stability of Klein's salt in iron-rich belite sulphoaluminate clinkers. They found that the optimum clinkering temperature, which corresponds to the largest overall amount of $\mathrm{C}_{4} \mathrm{~A}_{3} \hat{\mathrm{S}}$, was $1543 \mathrm{~K}\left(1270{ }^{\circ} \mathrm{C}\right)$ but that temperature could be decreased by the addition of boron and sodium to the raw materials. Due to the fact that CSA requires synthesis temperatures $200-300{ }^{\circ} \mathrm{C}$ lower than those required for the formation of $\mathrm{C}_{3} \mathrm{~S}$ in ordinary Portland cement, cements incorporating this phase are also called low-energy cements. Other raw materials used in calcium sulphoaluminate production are: limestone, bauxite, aluminium-rich clay and gypsum (9). Besides gypsum, hemihydrate, fluorgypsum and anhydrite are also used as a source of calcium sulphate (10). This compound generates as main crystalline phases ettringite $\left(\mathrm{C}_{6} \mathrm{AS}_{3} \mathrm{H}_{32}\right)$ and monosulphate when combined with water, lime and/or calcium sulphate (11). The early hydration of the CSA cements is mainly governed by the amount and reactivity of the added calcium sulphate $(12,13)$. In other investigations the early hydration of CSA in the presence of gypsum was studied with varying amounts of calcium hydroxide (14). Typically about $15-25 \mathrm{wt} \%$ of gypsum and/or anhydrite are interground with the clinker for optimum setting time, strength development and volume stability $(15,16)$. The $\mathrm{C}_{4} \mathrm{~A}_{3} \hat{\mathrm{S}}$ hydration has been studied by following the rate of ettringite formation and microstructural development. CSA based cements can be employed as shrinkage-resistant, self-stressing and high early strength cements. The process of rapid-hardening is due to the instantaneous formation of nonexpansive ettringite which develops relatively large crystals that are able to provide high mechanical strength at early ages (17). In systems with low calcium sulphate additions, the ettringite formation is terminated shortly after setting; thus, expansive ettringite reactions cannot occur. On the contrary, the expansive behaviour of systems with ettringite/gypsum molar ratios of about 1:2 and beyond is related to the ongoing formation of ettringite in systems after setting; such systems exhibit a rigid structure, in which further ettringite formation may cause expansion (18). The expansive effect of ettringite formation from the addition of calcium sulphates and materials rich in phases such as $\mathrm{CA}, \mathrm{C}_{4} \mathrm{~A}_{3} \hat{\mathrm{S}}$ or $\mathrm{C}_{3} \mathrm{~A}$, has been utilized to compensate shrinkage in special cements (19). The properties of CSA cements are strongly influenced by the addition of other cementive compounds such as strontium aluminate. Strontium aluminate based cements (SrAC) are produced by solid state reaction of $\mathrm{SrO}$ or $\mathrm{SrCO}_{3}$ and $\mathrm{Al}_{2} \mathrm{O}_{3}$ mixtures at $1500{ }^{\circ} \mathrm{C}$. The main constituent of these cements is the $\mathrm{SrO} \cdot \mathrm{Al}_{2} \mathrm{O}_{3}$. This phase hydrates slowly giving a hydration product with a formula $\mathrm{SrO} \cdot \mathrm{Al}_{2} \mathrm{O}_{3} \cdot 7-10 \mathrm{H}_{2} \mathrm{O}$. This kind of cement has potential applications in the production of high temperature resistant concretes (1). In the family of aluminous cements the potential of strontium aluminate has been sporadically studied without much wide-spread commercial success. Despite the long history and fairly extensive use of calcium aluminate cements, these display certain critical shortcomings in their hydration characteristics and application properties; this led to studies that commenced years ago to evaluate if the alkali-earth oxides like $\mathrm{SrO}$ could replace lime in the synthesis of aluminates (20). It is well known that the formation of the calcium aluminate hydrates depends on the temperature at which the reaction occurs. Like CAC, the SrAC also displays hydraulic behaviour in contact with water and converts into distrontium aluminate hydrate $\left(\mathrm{Sr}_{2} \mathrm{AHn}\right)$ and $\mathrm{AH}_{3}$. No time or temperaturedependent conversion deletereous phenomena were detected in the preliminary hydration studies. For non-refractory applications, SrAC holds a promising potential for making concretes with seawater resistance as well as for protections against radiation of X-rays and $\gamma$-rays (21). In this work, the effect of strontium aluminate and hemihydrate content were investigated in order to improve the properties of a CSA cement.

\section{EXPERIMENTAL}

Calcium sulphoaluminate $\left(\mathrm{C}_{4} \mathrm{~A}_{3} \hat{\mathrm{S}}\right)$ was synthesized at $1350{ }^{\circ} \mathrm{C}$ for $4 \mathrm{~h}$ from a stoichiometric mixture of commercial materials $\mathrm{CaCO}_{3}$ (OMYA S.A), $\mathrm{CaSO}_{4} \cdot 1 / 2 \mathrm{H}_{2} \mathrm{O}$ (Yesera Monterrey S.A.) and $\mathrm{Al}(\mathrm{OH})_{3}$ (Possehl S.A.). The obtained CSA was dry milled in order to obtain a material with a specific surface area within the range of $350-400 \mathrm{~m}^{2} / \mathrm{kg}$. The optimum time of milling was determined based on measurements of the specific surface area according to ASTM C-204 (22) (Equivalent to BS EN 196-6: 2010 (23)). Samples were prepared with different compositions by adding 15,20 or $25 \mathrm{wt} \%$ of $\mathrm{CaSO}_{4} \cdot 1 / 2 \mathrm{H}_{2} \mathrm{O}$ to the calcium sulphoaluminate. Some of the samples were mixed with 10 or $20 \mathrm{wt} \%$ of strontium aluminate $\left(\mathrm{SrAl}_{2} \mathrm{O}_{4}\right)$. Table 1 show the composition and the identification of the samples prepared.

In order to evaluate the properties of the samples, these were hydrated with distilled water using 
TABLE 1. Composition of samples prepared

\begin{tabular}{llllllllll}
\hline & \multicolumn{10}{c}{ Weight \% } \\
\cline { 2 - 11 } Compound & $\mathbf{s 1}$ & $\mathbf{s 2}$ & $\mathbf{s 3}$ & $\mathbf{s 4}$ & $\mathbf{s 5}$ & $\mathbf{s 6}$ & $\mathbf{s 7}$ & $\mathbf{s 8}$ & $\mathbf{s 9}$ \\
\hline $\mathbf{C}_{\mathbf{4}} \mathbf{A}_{\mathbf{3}} \hat{\mathbf{S}}$ & 85 & 76.5 & 68 & 80 & 72 & 64 & 75 & 67.5 & 60 \\
$\mathbf{C S} \mathbf{H}_{\mathbf{0 . 5}}$ & 15 & 13.5 & 12 & 20 & 18 & 16 & 25 & 22.5 & 20 \\
$\mathbf{S r A}$ & 0 & 10 & 20 & 0 & 10 & 20 & 0 & 10 & 20 \\
\hline
\end{tabular}

$\mathrm{CS}_{0.5}: \mathrm{CaSO}_{4} \cdot 1 / 2 \mathrm{H}_{2} \mathrm{O}$

$\mathrm{SrA}: \mathrm{SrAl}_{2} \mathrm{O}_{4}$.

w/c ratios of 0.4 and 0.5 . Pastes were cast in cubic moulds of $2.54 \mathrm{~cm}$ per side. Curing was carried out by immersing the cubes in water at a constant temperature of $20^{\circ} \mathrm{C}$. The setting time of the samples was evaluated according to ASTM-191 (24) (Equivalent to BS EN 196-3: 2005 (25)). The development of compressive strength was evaluated using an automated hydraulic press (Controls 50-C70024) with a capacity of $250 \mathrm{kN}$ and a loading rate of $350 \mathrm{~N} / \mathrm{s}$. Four cubes were tested, reporting the average for each time of curing. X-ray diffraction (XRD) was carried out in order to identify the phases present in some representative samples. Samples were taken from the cubes crushed in the compression tests and dried in a vacuum oven for $24 \mathrm{~h}$ at $35^{\circ} \mathrm{C}$; these were further ground to a particle size lower than 150 microns using a porcelain mortar. A Phillips PW 3040e diffractometer was employed using $\mathrm{CuK} \alpha$ radiation $(1.542 \AA)$ and a scanning range of 7-60 degrees $2 \theta$. Analyses by scanning electron microscopy (SEM) and energy dispersive X-ray spectroscopy (EDS) were made to observe the phases formed and the microstructure of the hydration products on fracture surfaces and polished samples mounted in epoxy resin. Analyses were carried out using a Phillips XL 30 SEM; EDS was performed at 2000 magnifications over a $100 \mu \mathrm{m}^{2}$ transversal area using $20 \mathrm{kV}$ and a working distance of $10 \mathrm{~mm}$. The samples were analysed using the technique of backscattered electrons for the observation of hydration products. Samples mounted in epoxy resin were abraded with $\mathrm{SiC}$ sand paper of $80,120,320,500,800$ and 1200 grit size and then polished with 1 and $0.25 \mathrm{~mm}$ diamond pastes. All samples were coated with graphite before analysis.

\section{RESULTS AND DISCUSSION}

Table 2 shows the initial and final setting times of the samples analysed. It was found that the setting time is influenced by the w/c ratio, the amount of hemihydrate and the strontium aluminate incorporated. As for the w/c ratio, an increase from 0.4 to 0.5 increased the setting time up to $42 \mathrm{~min}$ compared to samples without aluminate addition.
Similarly, the addition of the strontium aluminate had a retarding effect on the setting time. The addition of $10 \mathrm{wt} \%$ of strontium aluminate had greater retarding effect than $20 \mathrm{wt} \%$. Isothermal calorimetric studies indicated that the heat released during the early stages is higher for the sample with $20 \mathrm{wt} \%$ SrA $(21.2 \mathrm{~W} / \mathrm{kg})$ compared to that of the sample with $10 \mathrm{wt} \% \mathrm{SrA}(9.1 \mathrm{~W} / \mathrm{kg})$. This indicates that the hydration reactions occurred more rapidly in the latter, leading to lower setting times. According to ASTM C 150 (26) (Equivalent to BS EN 1971:2000 (27)), the initial setting of OPC must not be less than $45 \mathrm{~min}$ and the final setting not more than $375 \mathrm{~min}$.

Figure 1 shows the development of compressive strength as a function of curing time of samples with $15 \mathrm{wt} \%$ hemihydrate and w/c of 0.4 (a)

TABLE 2. Setting times of the samples analysed

\begin{tabular}{lccc}
\hline & & \multicolumn{2}{c}{ Setting time (min) } \\
\cline { 3 - 4 } Sample & w/c & Initial & Final \\
\hline \multirow{2}{*}{ s1 } & 0.4 & 13 & 21 \\
& 0.5 & 21 & 38 \\
s2 & 0.4 & 26 & 43 \\
& 0.5 & 50 & 92 \\
s3 & 0.4 & 14 & 31 \\
& 0.5 & 30 & 62 \\
s4 & 0.4 & 9 & 17 \\
& 0.5 & 19 & 33 \\
s5 & 0.4 & 24 & 39 \\
& 0.5 & 46 & 84 \\
s6 & 0.4 & 14 & 25 \\
& 0.5 & 27 & 52 \\
s7 & 0.4 & 7 & 12 \\
& 0.5 & 16 & 26 \\
s8 & 0.4 & 22 & 36 \\
& 0.5 & 42 & 78 \\
s9 & 0.4 & 13 & 21 \\
& 0.5 & 20 & 43 \\
\hline
\end{tabular}


and 0.5 (b), with 0,10 and $20 \%$ of $\mathrm{SrAl}_{2} \mathrm{O}_{4}$. The strength development was greatly influenced by the addition of $\mathrm{SrAl}_{2} \mathrm{O}_{4}$. Samples with 0 and $10 \mathrm{wt} \%$ additions behaved similarly since there was a decrease in strength after three days of curing followed by a subsequent increase. The maximum strength after $28 \mathrm{~d}$ of curing was 30.5 and $39 \mathrm{MPa}$ for $\mathrm{w} / \mathrm{c}=0.4$ and of 27.6 and $26.3 \mathrm{MPa}$ for $\mathrm{w} / \mathrm{c}=0.5$. The strength decrease at three days of curing was attributed to the delayed ettringite formation which occurs after submerging the samples in water after $1 \mathrm{~d}$ of curing. This ettringite was formed after the cement paste has hardened and because of the expansive nature of this phase, some cracking were generated. With the addition of $20 \mathrm{wt} \%$ of $\mathrm{SrAl}_{2} \mathrm{O}_{4}$ the reduction in the development of compressive strength at $7 \mathrm{~d}$ of curing was negligible. The maximum strengths reached at $28 \mathrm{~d}$ of curing were 53.5 and $31.1 \mathrm{MPa}$ for $\mathrm{w} / \mathrm{c}=0.4$ and $\mathrm{w} / \mathrm{c}=0.5$, respectively.

Figure 2 shows the development of compressive strength of samples with $20 \mathrm{wt} \%$ hemihydrate and w/c of 0.4 (a) and 0.5 (b) with the addition of 10 and $20 \mathrm{wt} \%$ of $\mathrm{SrAl}_{2} \mathrm{O}_{4}$. It was found that there was a favourable effect on the strength development by increasing the amount of hemihydrate. The maximum strength reached after $28 \mathrm{~d}$ with the addition of $10 \mathrm{wt} \%$ of $\mathrm{SrAl}_{2} \mathrm{O}_{4}$ were 43.2 and $33.4 \mathrm{MPa}$ using w/c of 0.4 and 0.5 , respectively. As in the samples with $15 \mathrm{wt} \%$ hemihydrate, the addition of $20 \mathrm{wt} \%$ $\mathrm{SrAl}_{2} \mathrm{O}_{4}$ had a great influence on the development of compressive strength as samples reached maximum values of 57 and $36.2 \mathrm{MPa}$ using w/c of 0.4 and 0.5 , respectively.

Figure 3 shows the graphs of compressive strength of samples with $25 \mathrm{wt} \%$ hemihydrate.
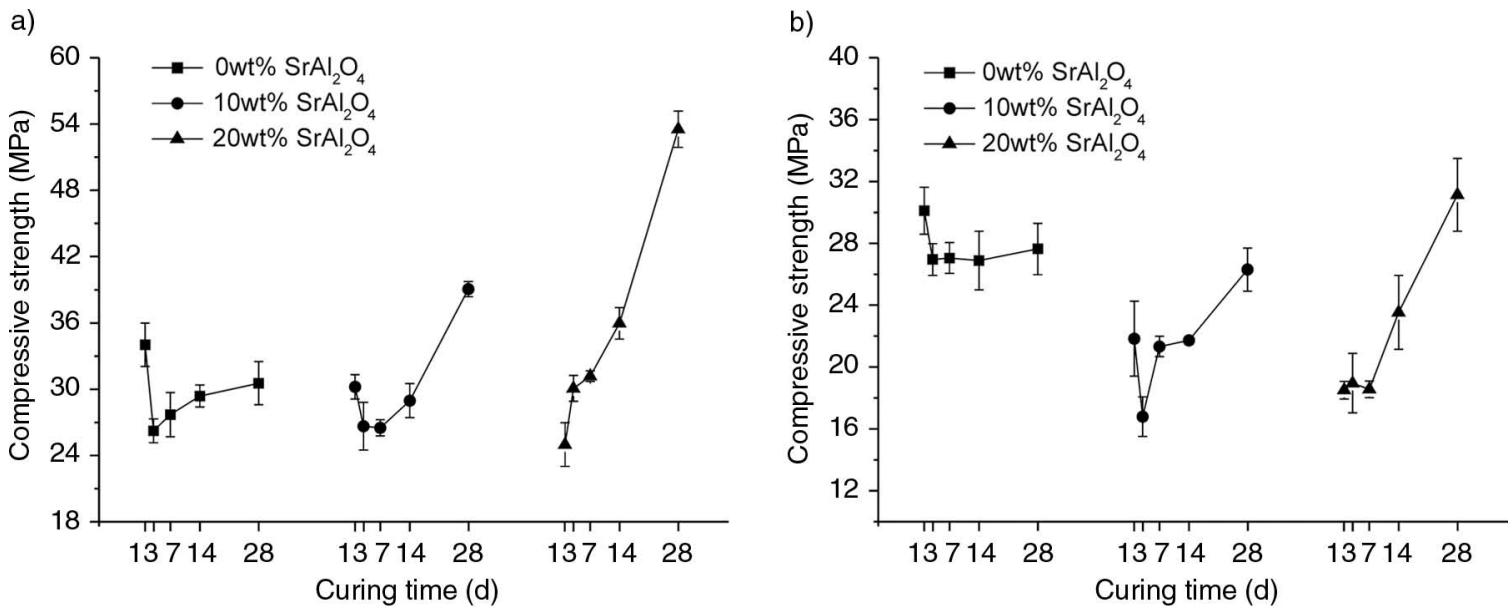

FIgURE 1. Compressive strength of samples with $15 \mathrm{wt} \%$ hemihydrate using w/c of 0.4 (a) and 0.5 (b).

a)

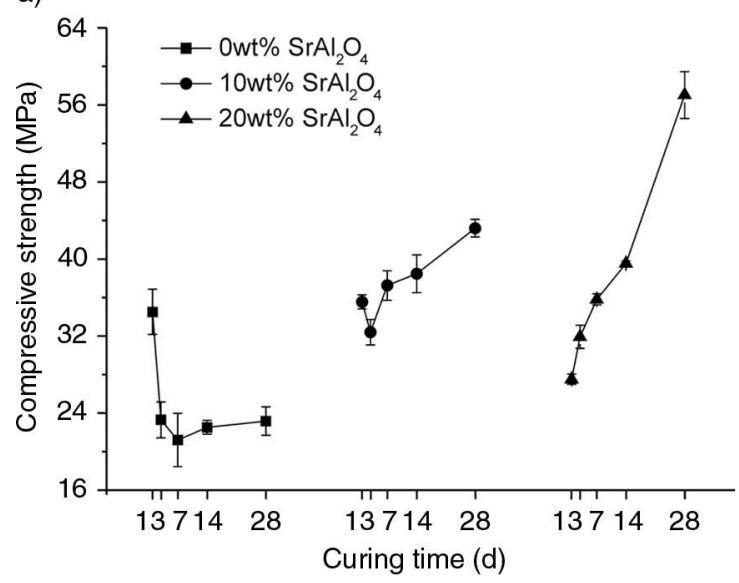

b)

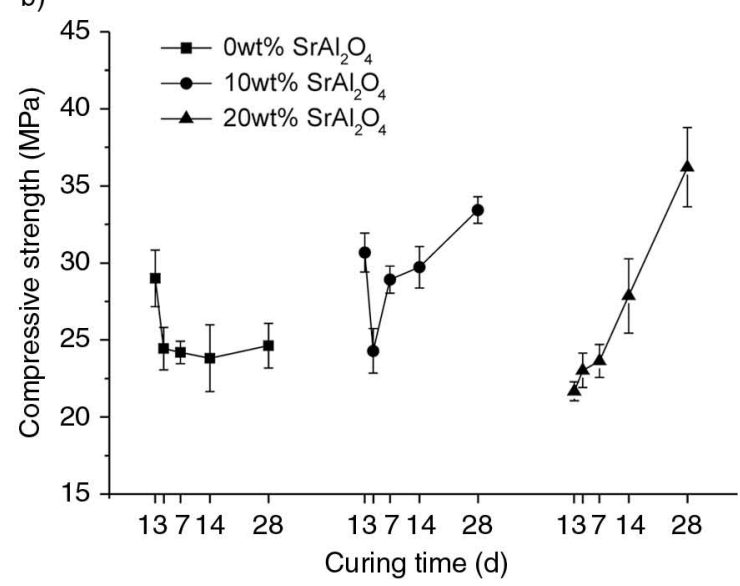

FIGURE 2. Compressive strength of samples with $20 \mathrm{wt} \%$ hemihydrate using w/c of 0.4 (a) y 0.5 (b). 
The evaluation of the compressive strength of the samples with a w/c ratio of 0.4 and without $\mathrm{SrAl}_{2} \mathrm{O}_{4}$ was not possible because of an excessive cracking in the samples. The addition of $\mathrm{SrAl}_{2} \mathrm{O}_{4}$ addition seems to avoid such cracking. A favourable effect on the strength development by was noted after increasing the amount of hemihydrate. The maximum 28 days strengths with the addition of $10 \mathrm{wt} \%$ of $\mathrm{SrAl}_{2} \mathrm{O}_{4}$ were 45.8 and $36.3 \mathrm{MPa}$ using w/c of 0.4 and 0.5 , respectively; whereas for $20 \mathrm{wt} \%$ of $\mathrm{SrAl}_{2} \mathrm{O}_{4}$ the strength reached maxima of 60.2 and $35.2 \mathrm{MPa}$ using w/c of 0.4 and 0.5 , respectively.

Figure 4 shows the XRD patterns corresponding to samples with 15, 20 and $25 \mathrm{wt} \%$ of hemihydrate containing $10 \mathrm{wt} \%$ (a) and $20 \mathrm{wt} \%$ (b) of $\mathrm{SrAl}_{2} \mathrm{O}_{4}$ after $28 \mathrm{~d}$ of curing. The main hydration product was the ettringite phase with its main peak located at $9.092 \theta$ degrees. Besides ettringite, monosulphate and a high portion of non-reacted calcium sulphoaluminate were found. No strontium aluminate hydrates could be detected and only a $\mathrm{Sr}\left(\mathrm{SO}_{4}\right)$ phase was found. As expected, the intensity of ettringite reflections increased with the hemihydrate content while that of calcium sulphoaluminate cement decreased.

Figure 5 shows the microstructure of the samples containing 15(a), 20(b) and 25(c)wt $\%$ hemihydrate and $10 \mathrm{wt} \% \mathrm{SrAl}_{2} \mathrm{O}_{4}$ using a w/c of 0.4 after $28 \mathrm{~d}$ of curing. Microanalysis by EDS indicates that large a)

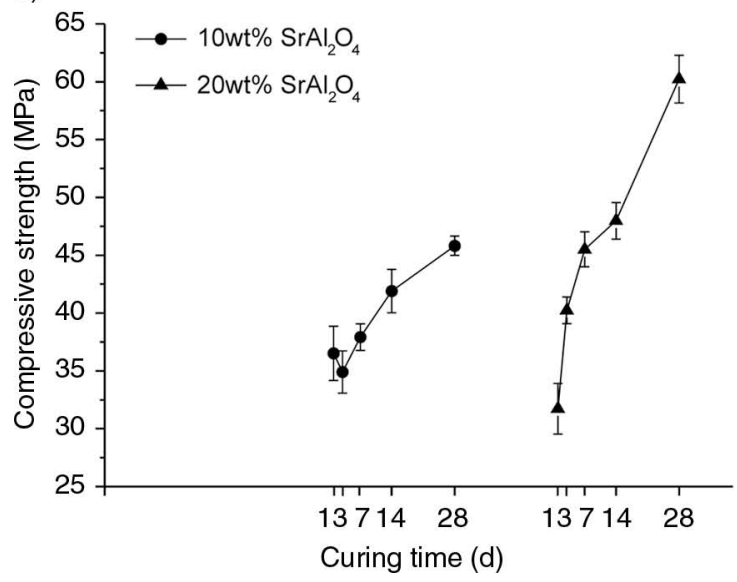

b)

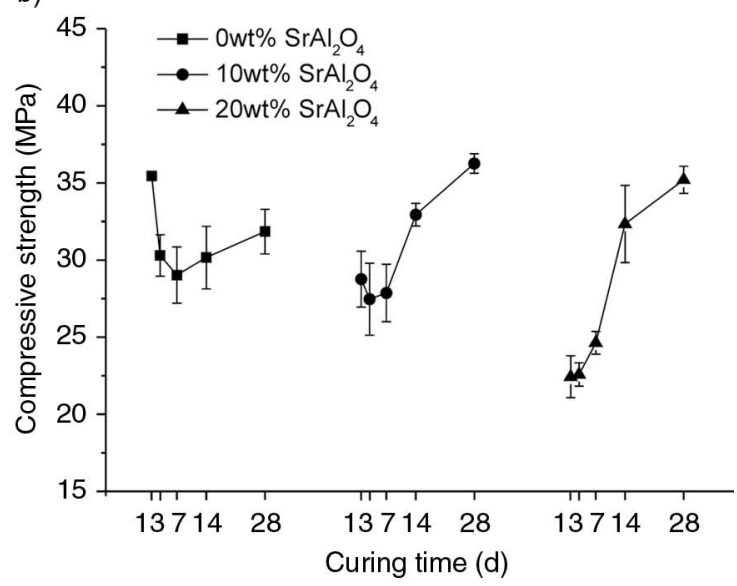

FIGURE 3. Compressive strength of samples with $25 \mathrm{wt} \%$ hemihydrate using w/c of 0.4 (a) y 0.5 (b).
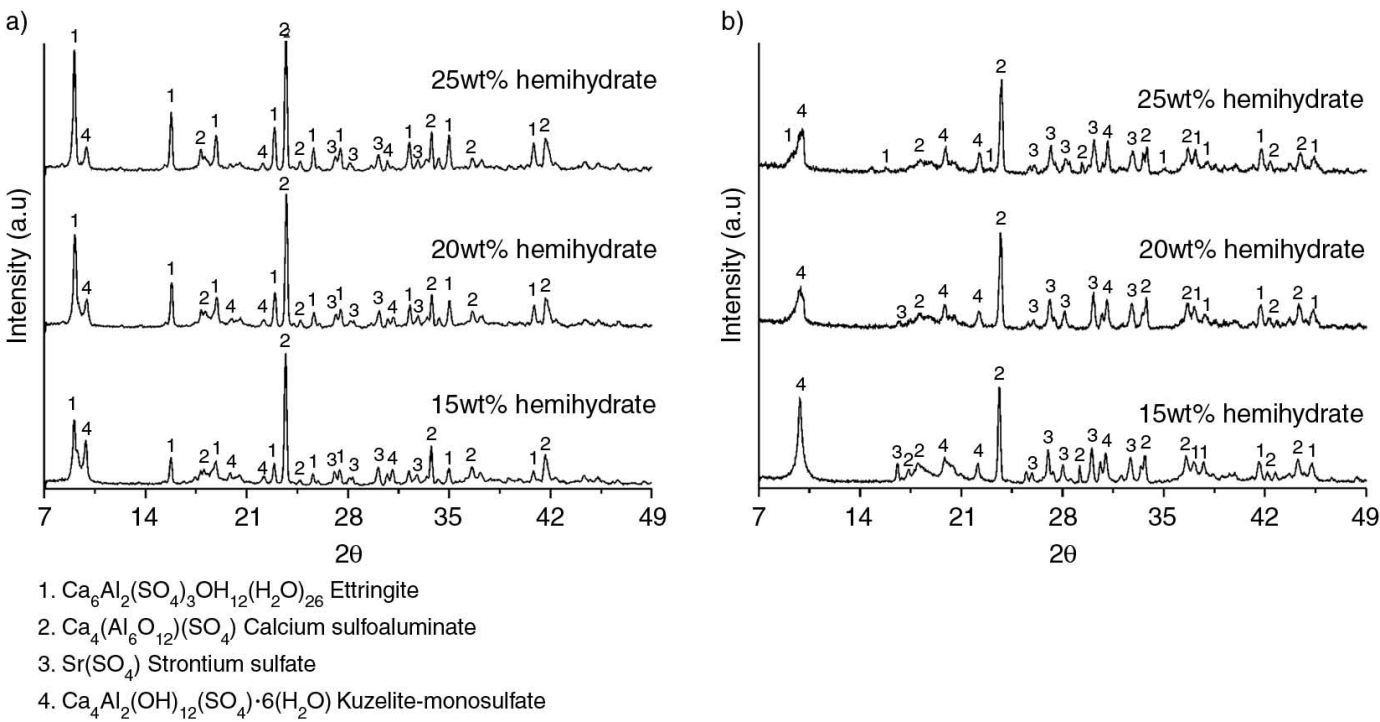

FIGURE 4. XRD patterns of samples with 15,20 and $25 \mathrm{wt} \%$ of hemihydrate containing $10 \%$ a) and $20 \mathrm{wt} \%$ b) of $\mathrm{SrAl}_{2} \mathrm{O}_{4}$ after $28 \mathrm{~d}$ of curing using $0.4 \mathrm{w} / \mathrm{c}$. 

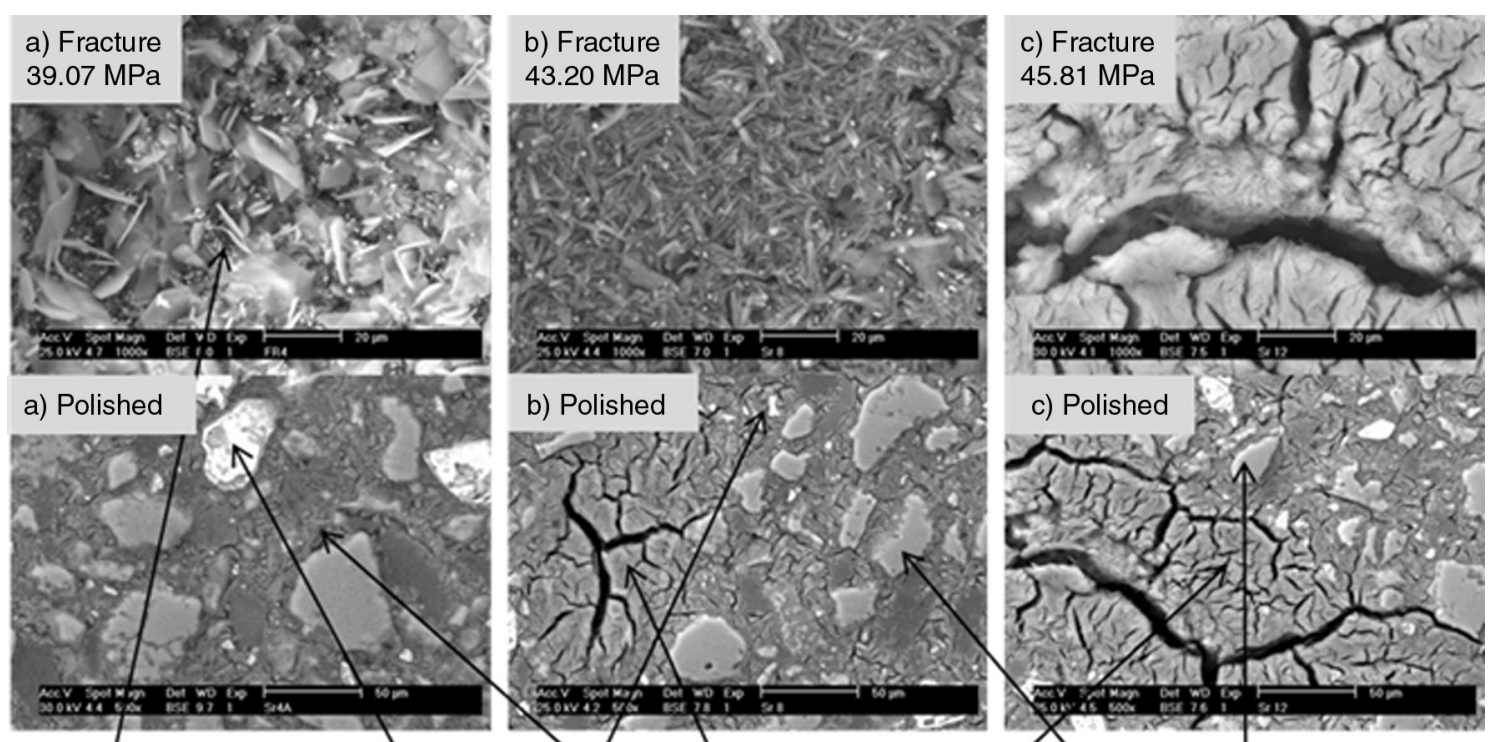

c) Polished
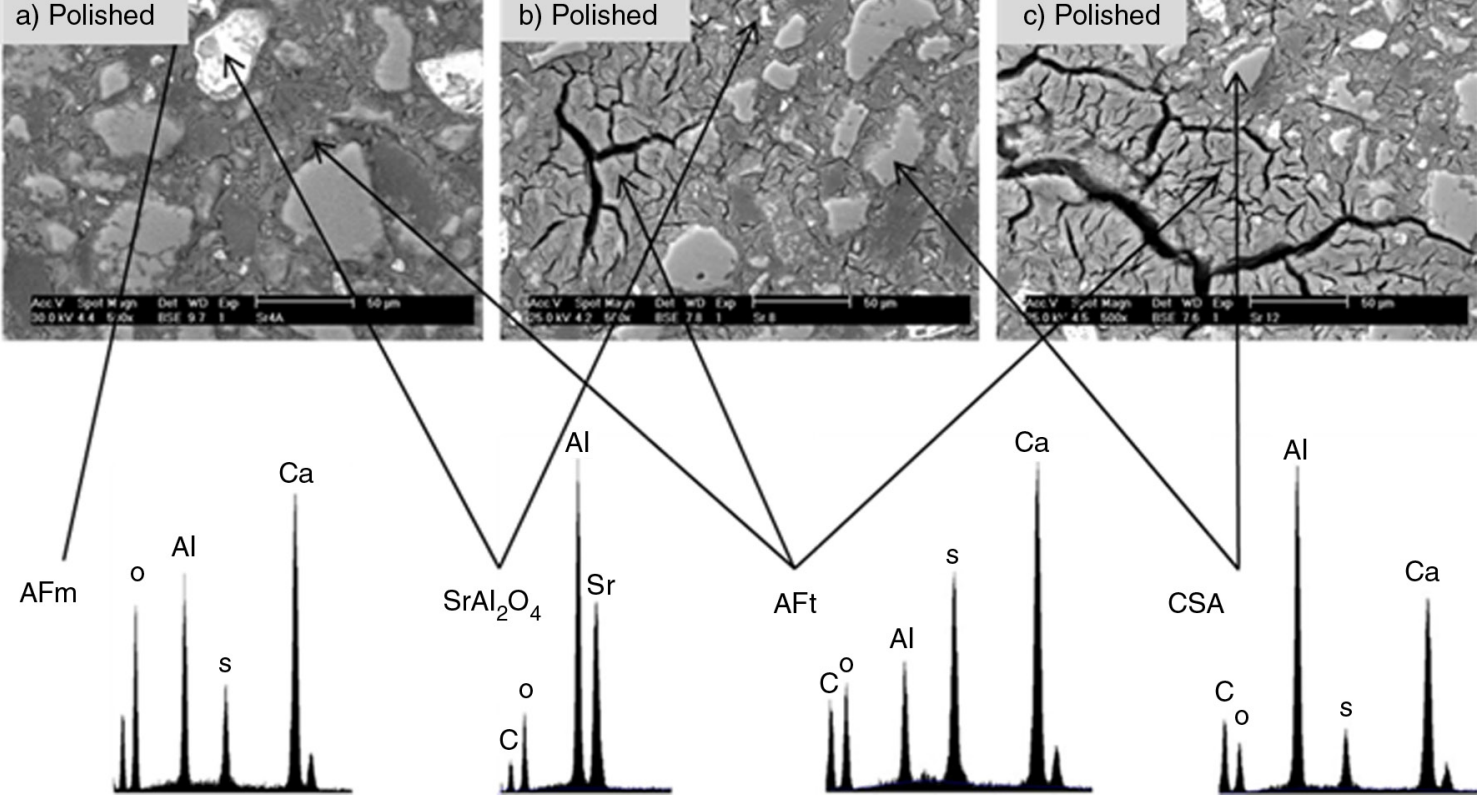

FIGURE 5. Micrographs of samples containing 15(a), 20(b) and 25(c)wt $\%$ of hemihydrate and $10 \mathrm{wt} \%$ of $\mathrm{SrAl}_{2} \mathrm{O}_{4}$ after $28 \mathrm{~d}$ of curing.

light-coloured particles correspond to a calcium sulphoaluminate phase and the matrix is mainly composed of ettringite, which is the main hydration product as indicated by DRX. It was observed that calcium sulphoaluminate was not completely reacted and that the formation of ettringite caused some cracking in the specimens, as can be noted in the fracture surfaces that showed the needlelike morphology of the latter. Figure 5(a) shows hexagonal plate-shaped particles which are attributed to monosulphate phase $(28,29)$. Figure $5(\mathrm{~b})$ shows needle-shaped crystals having a maximum length of $10 \mu \mathrm{m}$ and were homogeneously distributed througouth the analysed area. In Figure 5(c) it was observed how ettringite crystals have grown enough to impinge and form a cracked structure.

Figure 6 shows the microstructure of the samples containing $15(\mathrm{a}), 20(\mathrm{~b})$ and $25(\mathrm{c}) \mathrm{wt} \%$ of hemihydrate using a w/c of 0.4 and containing $20 \mathrm{wt} \%$ of $\mathrm{SrAl}_{2} \mathrm{O}_{4}$ after 28 days of curing. Micrographs show a partially reacted calcium sulphoaluminate particles surrounded by a matrix formed mostly by strontium aluminate. In these samples ettringite is observed as smaller but coarser needle-shaped crystals; it appears that the presence of $\mathrm{SrAl}_{2} \mathrm{O}_{4}$ inhibits the growth of ettringite crystals, avoiding an excessive cracking of the samples.

\section{CONCLUSIONS}

The addition of strontium aluminate has a retarding effect on the setting of the samples leading to obtain a crack-free cement with high strength. The setting time increased $42 \mathrm{~min}$ compared to samples without aluminate in samples with $15 \mathrm{wt} \%$ hemihydrate and $10 \mathrm{wt} \%$ of $\mathrm{SrAl}_{2} \mathrm{O}_{4}$. The water to cement ratio strongly influences the development of mechanical properties, those hydrated using a w/c of 0.4 develop higher strengths. Also, the addition of $\mathrm{SrAl}_{2} \mathrm{O}_{4}$ has a favourable effect on the development of compressive strength; the maximum values reached with 10 and $20 \mathrm{wt} \%$ of $\mathrm{SrAl}_{2} \mathrm{O}_{4}$ were 29.1 and 60.2 , respectively. Ettringite was the main hydration product having a hexagonal needle-shaped morphology growing on cement grains. Monosulphate phase was also found as hexagonal plate-shaped crystals. These cements are very promising materials for the construction industry. 

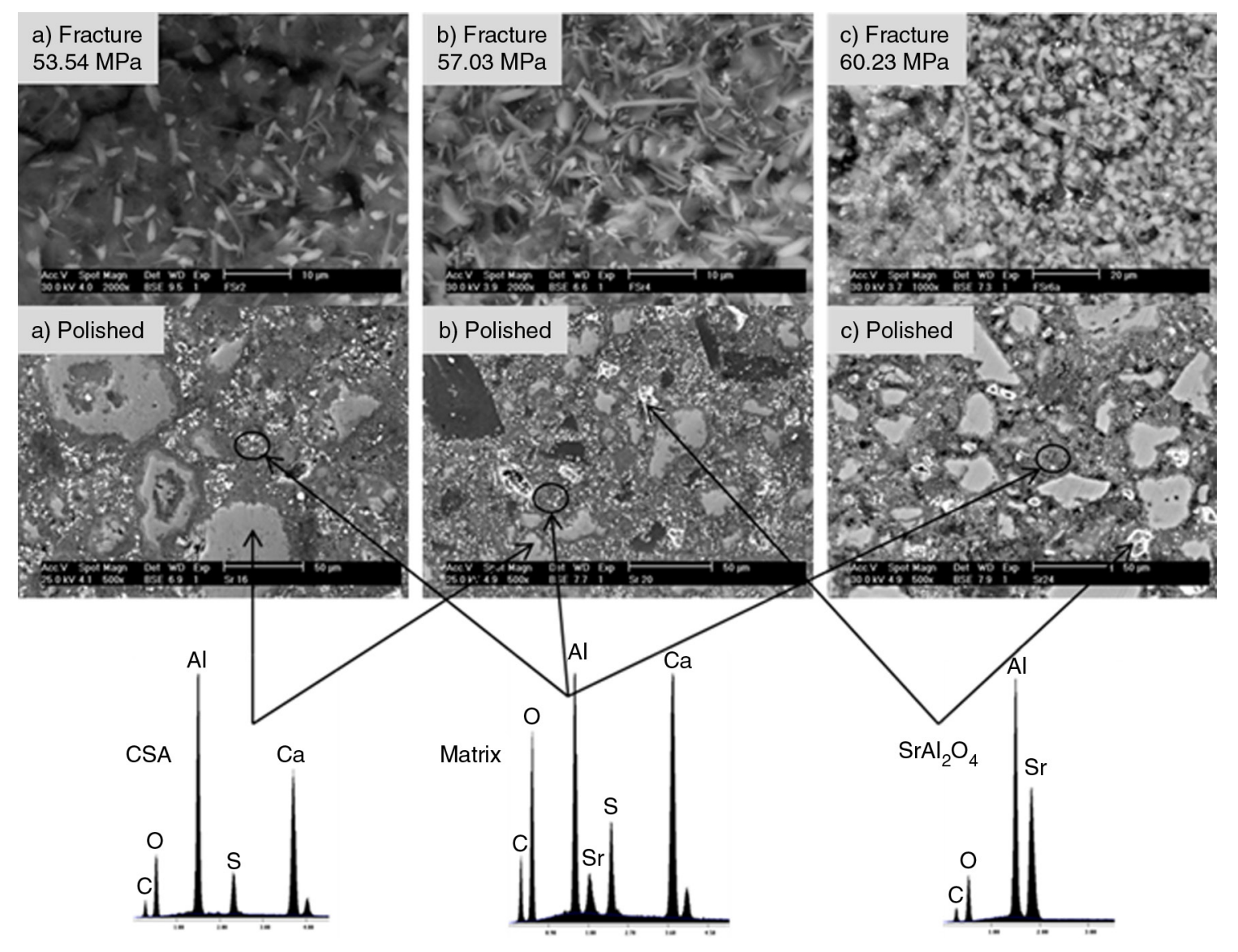

Figure 6. Micrographs of samples containing 15(a), 20(b) and 25(c)w $\%$ of hemihydrate and $20 \mathrm{wt} \%$ of $\operatorname{SrAl}_{2} \mathrm{O}_{4}$ after $28 \mathrm{~d}$ of curing.

\section{REFERENCES}

1. Odler, I. (2000) Special inorganic cements, E \& FN SPON, London.

2. Juenger, M.C.G.; Winnefeld, F. (2011) Advances in alternative cementitius binders. Cem. Concr. Res., 41 [12], 12321243. http://dx.doi.org/10.1016/j.cemconres.2010.11.012.

3. Propescu, C.D. (2003) Industrial trial production of low energy belite cement. Cem. Concr. Comp., 25 [7], 689-693. http://dx.doi.org/10.1016/S0958-9465(02)00097-5.

4. Aranda, M.A.G.; De la Torre, A.G. (2013) Sulfoaluminate cement, Ed. Pacheco-Torgal, F., Jalali, S., Labrincha, J., John, V. M. (Eds.), Eco-efficient concrete, Cambridge.

5. Saju, S.; Majling, J. (1993) Phase compatibility in the system $\mathrm{CaO}-\mathrm{SiO}_{2}-\mathrm{Al}_{2} \mathrm{O}_{3}-\mathrm{Fe}_{2} \mathrm{O}_{3}-\mathrm{SO}_{3}$ referred to sulphoaluminate belite cement clinker. Cem. Concr. Res., 23 [6], 1331-1339. http://dx.doi.org/10.1016/0008-8846(93)90070-P.

6. Quillin, K. (2001) Performance of belite-sulfoaluminate cements. Cem. Concr. Res., 31 [9], 1341-1349. http://dx.doi. org/10.1016/S0008-8846(01)00543-9.

7. Klein, A. (1965) Formation of Ettringite by Hydration of a System Containing an Anhydrous Calcium Sulfoaluminate. J. Am. Cer. Soc., 48 [8], 435-436. http://dx.doi.org/10. 1111/j.1151-2916.1965.tb14786.x.

8. De la Torre, A.G.; Cuberos, A.J.M. et al. (2011) In situ powder diffraction study of belite sulfoaluminate clinkering. Journal of Synchrotron Radiation, 18 [3], 506-514. http:// dx.doi.org/10.1107/S0909049511005796.

9. Glasser, F.P.; Zhang, L. (2001) High-performance cement matrices based on calcium sulfoaluminate-belite compositions. Cem. Concr. Res., 31 [12], 1881-1886. http://dx.doi. org/10.1016/S0008-8846(01)00649-4.
10. Arjunan, P. (1999) Sulfoaluminate-belite cement from lowcalcium fly ash and sulfur rich and other industrial byproducts. Cem. Concr. Res., 29 [8], 1305-1309. http:// dx.doi.org/10.1016/S0008-8846(99)00072-1.

11. Winnefeld, F. (2010) Hydration of calcium sulphoaluminate cements experimental findings and thermodinamic modeling. Cem. Concr. Res., 40 [1], 1239-1247. http:// dx.doi.org/10.1016/j.cemconres.2009.08.014.

12. Ambroise, P.J. (2004) New applications of calcium sulfoaluminate cement. Cem. Concr. Res., Vol. 34 [4], 671-676. http://dx.doi.org/10.1016/j.cemconres.2003.10.019.

13. Havlica, S.S. (1991) Hydration behaviour of sulphoaluminate belite cement in the presence of various calcium sulphates. Thermochimica Acta, 175 [1], 45-52. http://dx.doi. org/10.1016/0040-6031(91)80244-D.

14. Hargis, C.; Kircheim, A. (2013) Early hydration of calcium sulfoaluminato (synthetic ye'elemite, $\mathrm{C}_{4} \mathrm{~A}_{3} \hat{\mathrm{S}}$ ) in the presence of gypsum and varying amounts of calcium hydroxide. Cem. Concr. Res., 48 [1], 105-115. http://dx.doi. org/10.1016/j.cemconres.2013.03.001.

15. Wang, Y.; Su, M. (1994) The third cement series in China. World Cem., 25 [8], 6-10.

16. Zhang, L.; Su, M.; Wang, Y. (1999) Development of the use of sulfo- and ferroaluminate cements in China. Adv. Cem. Res., 11 [1], 15-21. http://dx.doi.org/10.1680/ adcr.1999.11.1.15.

17. Beretka, J.; Marroccoli, M. (1996) The influence of $\mathrm{C}_{4} \mathrm{~A}_{3} \hat{\mathrm{S}}$ content and W/S ratio on the performance of calcium sulfoaluminate-based cements. Cem. Concr. Res., 26 [11], 1673-1681. http://dx.doi.org/10.1016/S0008-8846(96) 00164-0.

18. Winnefeld, F.; Barlag, S. (2010) Calorimetric and thermogavimetric study on the influence of calcium sulfate on the 
hydration of ye'elimite. J. Therm. Anal. Calorim., 101 [3], 949-957. http://dx.doi.org/10.1007/s10973-009-0582-6.

19. Evju, C.; Hansen, S. (2001) Expansive properties of ettringite in a mixture of calcium aluminate cement, Portland cement and $\beta$-calcium sulfate hemihydrate. Cem. Concr. Res., 31 [2], 257-261. http://dx.doi.org/10.1016/S0008-8846 (00)00495-6

20. Braniski, A. (1957) Barium and strontium cements, Zement-Kalk-Gips, 5, 176-184.

21. Chatterjee, A.K. (2009) Re-examining the prospects of aluminous cements based on alkali-earth and rare-earth oxides. Cem. Concr. Res., 39 [11], 981-988. http://dx.doi.org/ 10.1016/j.cemconres.2009.07.027.

22. ASTM C-204, Fineness of Hydraulic Cement by Air Permeability Apparatus, 1995 Annual Book of ASTM Standards. Section 4. Construction. Vol. 04.01. Cement, Lime, Gypsum.

23. BS EN 196-6: 2010. Methods of testing cement. Part 6: Determination of fineness. London, British Standards Institute.
24. ASTM C-191, Test Method for Time of Setting of Hydraulic Cement by Vicat Needle, 1995 Annual Book of ASTM Standards. Section 4. Construction. Volume 04.01. Cement, Lime, Gypsum.

25. BS EN 196-3: 2005. Methods of testing cement. Part 3: Determination of setting and soundness. London, British Standards Institute

26. ASTM C 150 Standard Specification for Portland cement, 2004 Annual Book of ASTM Standards. Section 4. Construction. Vol. 04.01. Cement, Lime, Gypsum.

27. BS EN 197-1: 2000. Cement. Composition, specifications and conformity criteria for common cements. London, British Standards Institute.

28. Quennoz, A.; Scrivener, K.L. (2012) Hydration of $\mathrm{C}_{3} \mathrm{~A}-$ gypsum systems. Cem. Concr. Res., 42 [7], 1032-1041. http://dx.doi.org/10.1016/j.cemconres.2012.04.005.

29. Motzet, H.; Pöllmann, H. (1999) Synthesis and characterisation of sulfite-containing AFm phases in the system $\mathrm{CaO}-\mathrm{Al}_{2} \mathrm{O}_{3}-\mathrm{SO}_{2}-\mathrm{H}_{2} \mathrm{O}$. Cem. Concr. Res., 29 [7], 1005-1011. http://dx.doi.org/10.1016/S0008-8846(99)00082-4. 